\title{
AMP-Activated Protein Kinase $\alpha 1$ Regulates Cardiac Gap Junction Protein Connexin 43 and Electrical Remodeling Following Pressure Overload
}

\author{
Ioana Alesutan ${ }^{\mathrm{a}}$ Jakob Voelkla Florian Stöckigt ${ }^{\mathrm{b}}$ Sobuj Mia ${ }^{\mathrm{a}}$ Martina Feger \\ Uwe Primessnig ${ }^{c}$ Mentor Sopjania, ${ }^{\text {f }}$ Carlos Munoz ${ }^{a}$ Oliver Borst ${ }^{a, d}$ \\ Meinrad Gawaz ${ }^{d}$ Burkert Pieske ${ }^{c}$ Bernhard Metzlere Frank Heinzelc \\ Jan Wilko Schrickel ${ }^{b}$ Florian Lang ${ }^{a}$
}

aDepartment of Physiology, University of Tübingen, Tübingen, Germany; ${ }^{b}$ Department of Medicine Cardiology, University Hospital Bonn, Bonn, Germany; 'Div. of Cardiology, Medical University of Graz and Ludwig Boltzmann Institute for Translational Heart Failure Research, Graz, Austria; dDepartment of Cardiology and Cardiovascular Medicine, University of Tübingen, Tübingen, Germany; ${ }^{\text {DDepartment }}$

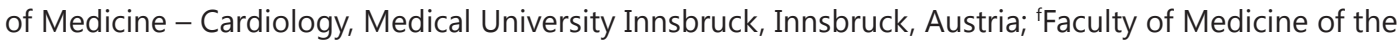
University of Prishtina, Prishtina, Kosova

\section{Key Words}

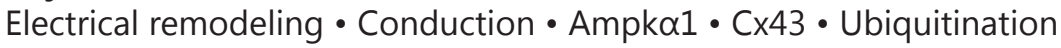

\begin{abstract}
Background/Aims: Adenosine 5'-monophosphate (AMP)-activated protein kinase (Ampk) modulates a wide array of cellular functions and regulates various ion channels and transporters. In failing human hearts an increased Ampk $\alpha 1$ activity was observed. The present study aimed to uncover the impact of Ampka1 on cardiac electrical remodeling. Methods: Gene-targeted mice lacking functional Ampk $\alpha 1$ (Ampk $\alpha 1^{-/}$) and corresponding wild-type mice were exposed to pressure overload by "transverse aortic constriction" (TAC). In vivo electrophysiology was performed with a single catheter technique, myocardial conduction velocities and conduction characteristics investigated in isolated hearts, transcript levels quantified by RTPCR and protein abundance determined by Western blotting. Moreover, connexin 43 (Cx43) was expressed in Xenopus oocytes with or without coexpression of wild-type or mutant AMPK and Cx43 protein abundance quantified utilizing confocal microscopy. Results: TAC treatment increased Ampk $\alpha 1$ protein expression in cardiac tissue from wild-type mice. TAC further increased left ventricular conduction inhomogeneity and triggered conduction blocks, effects blunted in the Ampka1 ${ }^{--}$mice. TAC treatment decreased $\mathrm{Cx} 43$ protein abundance in cardiac tissue, an effect significantly blunted in the Ampko1 $1^{-/}$mice. TAC treatment did not modify $\mathrm{C} x 43$ mRNA levels but increased ubiquitination of $\mathrm{Cx} 43$ protein, an effect mitigated by Ampk $\alpha 1$ deficiency. As shown in Xenopus oocytes, $\mathrm{C} \times 43$ cell membrane protein abundance

I. Alesutan and J. Voelkl contributed equally and thus share first authorship.

Prof. Dr. med. Dr. h.c. Florian Lang

Department of Physiology, University of Tübingen,

Gmelinstr. 5, D-72076 Tübingen (Germany)

Tel. +49-7071-2972194, Fax +49-7071-295618, E-Mail florian.lang@uni-tuebingen.de
\end{abstract}

KARGER 125 
was significantly downregulated by wild-type AMPKWT and constitutively active AMPKYR70Q, but not by catalytically inactive AMPK ${ }^{\alpha K 45 R}$. Conclusion: Ampk $\alpha 1$ stimulates ubiquitination of the gap junction protein $\mathrm{Cx} 43$, thereby contributing to gap junction remodeling following pressure overload.

Copyright $\odot 2015$ S. Karger AG, Basel

\section{Introduction}

Electrical coupling by gap junctions is essential for action potential propagation throughout cardiac muscle [1]. Connexin $43(\mathrm{Cx} 43)$ is the major gap junction protein in ventricular myocytes [1]. Cx43-dependent gap junction coupling underlies dynamic alterations [2]. In failing hearts, "electrical remodeling" modifies activity of ion channels, excitation-contraction coupling and intercellular gap junctions [3]. Electrical remodeling is a hallmark of cardiac failure [3] which is associated with high morbidity and mortality at least partially due to fatal arrhythmias [4]. Cardiac electrical remodeling involves altered function of the gap junction protein $\mathrm{Cx} 43$ [1].

A crucial regulator involved in the myocardial stress response is adenosine 5'-monophosphate (AMP)-activated protein kinase (Ampk) [5]. Ampk is activated by increase of cytosolic $\mathrm{Ca}^{2+}$ concentration as well as AMP/ATP concentration ratio and thus senses cellular $\mathrm{Ca}^{2+}$ overload and energy depletion [6]. Ampk is a heterotrimer consisting of a catalytic alpha $(\alpha)$ subunit and regulatory beta $(\beta)$ and gamma $(\gamma)$ subunits [5]. Two isoforms of the catalytic $\alpha$ subunit exist with distinct subcellular localization: Ampk $\alpha 1$ (encoded by the Prkaa1 gene) found in the non-nuclear fraction and Ampk $\alpha 2$ (encoded by the Prkaa2 gene) localized in both nucleus and non-nuclear fraction [7].

In cardiac tissue, Ampk $\alpha 2$ is the dominant isoform and plays an important role in cardiac ischemia, hypertrophy and failure [5]. Ampk activity is increased in left ventricular (LV) hypertrophy, which reduces expression of the Ampko 2 isoform but increases the expression of the Ampk $\alpha 1$ isoform [8]. The contribution of Ampk $\alpha 1$ to Ampk activity is more pronounced in human than in mouse hearts [9]. In the failing human heart, the activity of the catalytic Ampko isoforms is shifted towards Ampko1 [9].

Ampk is a powerful regulator of channels, carriers and $\mathrm{Na}^{+} / \mathrm{K}^{+}$ATPase [10-19]. The kinase is involved in the regulation of cardiac sodium and potassium channels $[11,17]$. Ampko1 further downregulates gap junction protein beta 2 [12]. Mutations in the Ampk $\gamma 2$ subunit leading to increased Ampk activity are associated with cardiac electrophysiologic abnormalities, hypertrophy and glycogen storage disease [20].

The present study investigated the role of Ampka1 on cardiac electrophysiology and gap junction remodeling during pressure overload. To this end, cardiac electrical remodeling and $\mathrm{Cx} 43$ expression were measured in gene-targeted mice lacking functional Ampko1 (Ampko1\%) and corresponding wild-type mice exposed to pressure overload by "transverse aortic constriction" (TAC).

\section{Materials and Methods}

\section{Murine aortic banding}

All animal experiments were conducted according to the German law for the welfare of animals and were approved by local authorities. Ampk $\alpha 1$ knockout mice were described previously [21, 22]. Male mice of 9-12 weeks of age were used for the experiments. Cardiac pressure overload was induced by transverse aortic constriction (TAC) [23]. Briefly, mice were anaesthetized and placed on a heating pad. After orotracheal intubation and ventilation (Harvard minivent, Harvard Apparatus, Holliston, USA), the intercostal space was opened by a small incision in the muscular thoracic wall. The transverse aorta was exposed and constricted between the brachiocephalic artery and the left carotid artery by the width of a 27-G canula using a 7-0 filament. Sham treatment was performed similarly but without constriction of the filament. Animals were treated with buprenorphine $(0.05 \mathrm{mg} / \mathrm{kg} \mathrm{BW})$ after the procedure. 


\section{Electrophysiological investigation}

The in vivo electrophysiological investigations (EPI) were carried out with a single catheter technique [24]. Under inhalative anaesthesia (isoflurane; induction period 2.5 vol.\%, maintenance 1.2 vol.\% in $70 \%$ $\mathrm{N}_{2} \mathrm{O} / 30 \% \mathrm{O}_{2}$ ) the jugular vein was dissected and a 2-French octapolar mouse electrophysiological catheter (Ciber Mouse, NuMed Inc., NY, USA) was positioned into the right cardiac cavities on atrial and ventricular level.

Functional electrophysiological parameters were examined using a universal isolated stimulator (Hugo Sachs Elektronik, Type 263, Germany) and custom written software (Stimulus V3.2, H. Begerau, Bonn, Germany). Refractory periods were determined according to established procedure protocols [25]. The susceptibility to ventricular tachyarrhythmias (VTs) was determined by ventricular extrastimulus pacing (S1S1: $120 \mathrm{~ms}, 100 \mathrm{~ms}$, and $80 \mathrm{~ms}$ followed by up to 3 extra beats) and ventricular burst stimulation (1s at S1S1: $50-10 \mathrm{~ms}, 10 \mathrm{~ms}$ stepwise reduction; stimulus voltages 1.5 and $3.0 \mathrm{~V}$ ). VTs were defined as $\geq 4$ consecutive ventricular ectopic beats.

\section{Langendorff-perfusion and epicardial mapping}

Myocardial conduction velocities and conduction characteristics were investigated after excorporation of the hearts and Langendorff-perfusion with Krebs-Henseleit buffer at constant pressure $(80 \mathrm{mmHg}$; Langendorff apparatus by Radnoti Technologies, Monrovia, CA, USA; perfusate composition: $\mathrm{NaCl} 110 \mathrm{mM}$, $\mathrm{KCl} 4.6 \mathrm{mM}, \mathrm{MgSO}_{4} 1.2 \mathrm{mM}, \mathrm{CaCl}_{2} 2 \mathrm{mM}, \mathrm{NaH}_{2} \mathrm{PO}_{4} 2 \mathrm{mM}, \mathrm{NaHCO}_{3} 25 \mathrm{mM}$, glucose $8.3 \mathrm{mM}$, Na-pyruvate 2 $\mathrm{mM}$, gassed with carbogen $\left(\mathrm{O}_{2} 95 \%, \mathrm{CO}_{2} 5 \%\right), \mathrm{pH} 7.35-7.45$, temperature $\left.37^{\circ} \mathrm{C}\right)$ as previously described [26]. Using a 72-electrode array (FlexMEA72, Multi Channel Systems, Reutlingen, Germany, interelectrode distance: longitudinal $750 \mu \mathrm{m}$, transversal $625 \mu \mathrm{m}) 76$ activation maps in spontaneous sinus rhythm were analyzed from left ventricular epicardium (Cardio 2D Software, V2.0.3, Multi Channel Systems, Reutlingen, Germany). Considering the direction of the electrode array in relationship to the myocardial fiber orientation, longitudinal and transversal conduction velocities could be calculated. The inhomogeneity index as an index of local conduction slowing for each electrode [27] was calculated using custom-programmed software (Latency version 3.0; H. Begerau, Bonn, Germany). Significant conduction blocks were defined as conduction delay of $>4 \mathrm{~ms}$ between adjacent electrodes.

\section{Quantitative RT-PCR}

Total RNA was isolated from snap frozen murine heart samples using Trifast Reagent (Peqlab, Erlangen, Germany) according to the manufacturer's instructions. Reverse transcription of $2 \mu \mathrm{g}$ RNA was performed using oligo(dT) $)_{12-18}$ primers (Invitrogen, Karlsruhe, Germany) and SuperScript III Reverse Transcriptase (Invitrogen, Karlsruhe, Germany). cDNA samples were treated with RNase H (Invitrogen, Karlsruhe, Germany). Quantitative real-time PCR was performed with the iCycler $\mathrm{iQ}^{\mathrm{TM}}$ Real-Time PCR Detection System (Bio-Rad Laboratories, Hercules, CA) and iQ Sybr Green Supermix (Bio-Rad Laboratories, Hercules, CA) according to the manufacturer's instructions. The following primers were used $\left(5^{\prime} \rightarrow 3^{\prime}\right.$ orientation):

CX43 fw: ACAAGGTCCAAGCCTACTCCA;

CX43 rev: CCGGGTTGTTGAGTGTTACAG;

Gapdh fw: AGGTCGGTGTGAACGGATTTG;

Gapdh rev: TGTAGACCATGTAGTTGAGGTCA;

Prkaa1 fw: GACCGGACATAAAGTGGCTGT;

Prkaa1 rev: CCACGTCAAGGCTCCGAAT;

Prkaa2 fw: ATGGTTGTCCATAGGGACCTG;

Prkaa2 rev: GCGATCCACAGCTAGTTCGTAG.

The specificity of the PCR products was confirmed by analysis of the melting curves and in addition by agarose gel electrophoresis. All PCRs were performed in duplicate and relative mRNA fold changes were calculated by the $2^{-\Delta \Delta \mathrm{Ct}}$ method using Gapdh as internal reference.

\section{Immunostaining and confocal microscopy}

For immunohistochemistry [28], cardiac tissues were immediately frozen in mounting medium (Tissue-Tek, Sakura Finetek) and sectioned at a thickness of $8 \mu \mathrm{m}$ on coated slides. Heart sections were dried for $30 \mathrm{~min}$ at RT and fixed in methanol for $10 \mathrm{~min}$ at RT. To reduce nonspecific background staining, slides were incubated with 5\% normal goat serum in PBS/ 0.1\% Triton X-100 for 1 hour at RT. Sections were 
incubated overnight at $4^{\circ} \mathrm{C}$ with rabbit polyclonal anti-Cx43 antibody (diluted 1:50, Cell Signaling). Binding of primary antibody was visualized using goat anti-rabbit Alexa Fluor488-conjugated antibody (diluted 1:1,000, Invitrogen) incubated for 1 hour at RT. Nuclei were stained using DRAQ-5 dye (diluted 1:1,000, Biostatus) and actin using Rhodamine Phalloidin (diluted 1:100, Invitrogen). The slides were mounted with Prolong Gold antifade reagent (Invitrogen). Images were collected with a confocal laser-scanning microscope (LSM 510, Carl Zeiss MicroImaging GmbH) using a water immersion A-Plan ×40/1.2W DICIII. Confocal images are representative for 4 mice/ group. Negative controls were carried out simultaneously with all experiments by omitting incubation with primary antibody.

\section{Analysis of Cx43 ubiquitination}

Murine heart tissues were lysed with ice-cold IP lysis buffer (Thermo Fisher Scientific, Rockford, IL, USA) supplemented with complete protease and phosphatase inhibitor cocktail (Thermo Fisher Scientific, Rockford, IL, USA). After centrifugation at $10000 \mathrm{rpm}$ for $5 \mathrm{~min}$, protein concentration was determined by Bradford assay (Biorad Laboratories, Hercules, CA). Immunoprecipitation of Cx43 from heart tissue samples was performed by using Pierce Direct IP kit (Thermo Fisher Scientific, Rockford, IL, USA) according to the manufacturer's instructions. To pre-clear the lysate, fixed amounts of protein $(600 \mu \mathrm{g})$ were incubated with control agarose resine (Thermo Fisher Scientific, Rockford, IL, USA) for 1 hour at $4{ }^{\circ} \mathrm{C}$ on a rotator. Coupling of $4 \mu \mathrm{l}$ rabbit polyclonal anti-Cx43 antibody (Cell Signaling) to the AminoLink Plus coupling resin (Thermo Fisher Scientific, Rockford, IL, USA) was performed for 2 hours at RT. The pre-cleared lysate was incubated with the immobilized antibody to form the immune complex overnight at $4{ }^{\circ} \mathrm{C}$ on a rotator. Then, immune complexes were washed to remove non-bound proteins and low $\mathrm{pH}$ elution buffer was used to dissociate the bound antigen from the antibody. The eluted proteins were boiled in Roti-Load1 Buffer (Carl Roth GmbH, Karlsruhe, Germany) by heating for $5 \mathrm{~min}$ at $95^{\circ} \mathrm{C}$. Proteins were separated on $10 \%$ SDS-polyacrylamide gels and transferred to PVDF membranes. The membranes were incubated overnight at $4^{\circ} \mathrm{C}$ with rabbit antiubiquitin antibody (diluted 1:1000, Cell Signaling, Danvers, MA, USA) and then with goat anti-rabbit HRPconjugated antibody (diluted 1:1000, Cell Signaling) for 1 hour at RT. To remove antibodies, membranes were incubated in stripping buffer (Thermo Fisher Scientific, Rockford, IL, USA) for 10 min at RT and reprobed with rabbit polyclonal anti-Cx43 antibody (diluted 1:1000, Cell Signaling). Antibody binding was detected with the ECL detection reagent (Thermo Fisher Scientific, Rockford, IL, USA) and bands were quantified using Quantity One Software (Bio-Rad, München, Germany). Results are shown as the ratio of ubiquitin to $\mathrm{Cx} 43$ protein normalized to the sham treated wild-type mice.

\section{Western blot analysis}

Murine heart tissues were lysed with ice-cold IP lysis buffer (Thermo Fisher Scientific) supplemented with complete protease and phosphatase inhibitor cocktail (Thermo Fisher Scientific). After centrifugation at $10000 \mathrm{rpm}$ for $5 \mathrm{~min}$, protein concentration was estimated by Bradford assay (Biorad Laboratories, Hercules, CA) and proteins were boiled in Roti-Load1 Buffer (Carl Roth $\mathrm{GmbH}$ ) at $100^{\circ} \mathrm{C}$ for $10 \mathrm{~min}$. Proteins were separated on SDS-polyacrylamide gels and transferred to PVDF membranes. The membranes were incubated overnight at $4{ }^{\circ} \mathrm{C}$ with the following primary antibodies: rabbit monoclonal anti-Ampk $\alpha 1$ antibody (diluted 1:1000, Novus Biologicals), rabbit monoclonal anti-phospho-Ampk $\alpha$ (Thr ${ }^{172}$ ) antibody, rabbit monoclonal anti-Ampk $\alpha$ antibody, rabbit polyclonal anti-phospho-ACC $\left(\operatorname{Ser}^{79}\right)$ antibody, rabbit polyclonal anti-ACC antibody, rabbit polyclonal anti-Cx43 antibody and rabbit anti-GAPDH antibody (diluted 1:1000, Cell Signaling) and then with secondary goat anti-rabbit HRP-conjugated antibody (diluted 1:1000, Cell Signaling) for 1 hour at RT. For loading controls, the membranes were stripped with stripping buffer (Thermo Fisher Scientific, Rockford, IL, USA) for $10 \mathrm{~min}$ at RT. Antibody binding was detected with the ECL detection reagent (Thermo Fisher Scientific). Bands were quantified with Quantity One Software (Bio-Rad Laboratories) and results are shown as the ratio of phosphorylated to total protein to Gapdh and as the ratio of total protein to Gapdh normalized to the sham treated wild-type mice.

\section{Constructs}

For generation of cRNA, constructs were used encoding AMPK $\alpha 1-\mathrm{HA}, \mathrm{AMPK} \beta 1$-Flag, AMPK $\gamma 1-\mathrm{HA}$ [29], constitutively active mutant ${ }^{\mathrm{R} 700} \mathrm{AMPK} \gamma 1-\mathrm{HA}$ [30] and kinase-dead mutant ${ }^{\mathrm{K} 45 \mathrm{R}} \mathrm{AMPK} \alpha 1-\mathrm{HA}$ [31] in POL1, Xenopus oocyte expression vector and mouse tagged Cx43-eGFP inserted in the plasmid pSGEM, Xenopus oocyte expression vector. The construct for mouse $\mathrm{Cx} 43$-eGFP was obtained by subcloning the insert into 
pSGEM vector from pMJ-Cx43-eGFP (kind gift from Prof. Dr. Klaus Willecke) using EcoRI - NotI restriction sites. The eGFP-tagged Cx43 construct was sequenced to confirm the insert and tag in frame. cRNA was synthesized as described previously [32, 33].

Confocal microscopy in Xenopus oocytes

Xenopus oocytes were prepared as previously described $[34,35]$. cRNA $(4.6 \mathrm{ng})$ encoding either

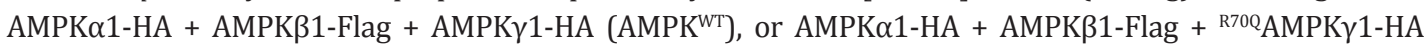
$\left(\mathrm{AMPK}^{\gamma \mathrm{R} 700}\right)$ or ${ }^{\mathrm{K} 45 \mathrm{R}} \mathrm{AMPK} \alpha 1 \mathrm{KD}-\mathrm{HA}+\mathrm{AMPK} \beta 1-\mathrm{Flag}+\mathrm{AMPK} \gamma 1-\mathrm{HA}\left(\mathrm{AMPK}^{\alpha \mathrm{K} 45 \mathrm{R}}\right)$ were injected on the first day and 23 ng of cRNA encoding Cx43-eGFP on the third day after preparation of the Xenopus oocytes $[19,36]$. All experiments were performed 3 days after the first injection. Oocytes were maintained at $17^{\circ} \mathrm{C}$ in ND96-A solution containing $88.5 \mathrm{mM} \mathrm{NaCl}, 2 \mathrm{mM} \mathrm{KCl}, 1.8 \mathrm{mM} \mathrm{CaC1}_{2}, 1 \mathrm{mM} \mathrm{MgC1}{ }_{2}, 5 \mathrm{mM}$ HEPES, 0.11 $\mathrm{mM}$ tretracycline, $4 \mu \mathrm{M}$ ciprofloxacin, $0.22 \mathrm{mM}$ gentamycin (Refobacin), $0.5 \mathrm{mM}$ of the oocyte maturation inhibitor theophylline (Euphylong) [37], and $5 \mathrm{mM}$ sodium pyruvate. The $\mathrm{pH}$ was adjusted to 7.4.

To visualize Cx43-eGFP cell surface expression, Xenopus oocytes were fixed in 4\% paraformaldehyde/ PBS for 2 hours at RT. After washing with PBS, Xenopus oocytes were analyzed by a fluorescence laser scanning microscope (LSM510, CarlZeiss MicroImaging GmbH, Germany) with A-Plan 10x/0.25, focused on the midline of the oocytes. Brightness and contrast settings were kept constant during imaging of all oocytes in each injection series. Confocal images are representative for three independent experiments. The fluorescence intensity reflecting Cx43-eGFP membrane abundance was quantified by ZEN2009 software (Zeiss, Göttingen, Germany) [38].

Statistics

Data are shown as arithmetic means \pm SEM unless indicated otherwise. Normality was tested with Shapiro-Wilk test. Non-normal data were transformed (log or reciprocal) prior to statistical testing to provide normality according to Shapiro-Wilk test. Statistical testing was performed by one-way Anova followed by Tukey-test for homoscedastic data or Games-Howell test for heteroscedastic data. Non-normal data was tested by the Steel-Dwass method. Two groups were compared by unpaired two-tailed t-test. Left ventricular conduction blocks are shown as individual measurements and box-plots (generalized linear model, exponential distribution). The probability of VT is shown descriptive. A p $<0.05$ was considered statistically significant.

\section{Results}

A first series of experiments explored whether cardiac Ampk $\alpha 1$ expression is modified following pressure overload induced by transverse aortic constriction (TAC). As a result, in wild-type mice $\left(A m p k \alpha 1^{+/+}\right), 2$ weeks of TAC treatment significantly increased cardiac Ampk $\alpha 1$ protein abundance compared to sham treated mice (Fig. 1A). TAC treatment did not significantly modify Prkaa1 and Prkaa2 mRNA levels (Fig.1B). The Ampk $\alpha$ protein abundance was increased following TAC treatment without modifying ACC (Acetyl-CoA carboxylase) phosphorylation, a target phosphorylated by Ampk [39] (Fig. 1C).

To investigate whether Ampk $\alpha 1$ is involved in electrical remodeling of the heart, electrophysiological investigations and cardiac mapping were performed on hearts from Ampk $\alpha 1^{+/+}$mice and Ampk $\alpha 1$ knockout mice (Ampk $\alpha 1^{-/}$) following TAC or sham procedure (Fig. 2). TAC treatment led to an increase of the LV inhomogeneity index in Ampk $\alpha 1^{+/+}$hearts as compared to sham treated hearts, effects significantly blunted in the Ampk $\alpha 1^{\%}$ hearts (Fig. 2B). Furthermore, following TAC treatment, Ampk $\alpha 1^{+/+}$hearts displayed more conduction blocks $>4 \mathrm{~ms}$ than Ampk $\alpha 1^{-\%}$ hearts (Fig. 2C). Surprisingly, both longitudinal and transversal conduction velocity tended to be lower in Ampk $\alpha 1^{-/}$hearts as compared to Ampk $\alpha 1^{+/+}$hearts, irrespective of TAC treatment (Fig. 3 A,B). The conduction velocity was not further reduced by TAC treatment in Ampk $\alpha 1 \%$ hearts. Longitudinal conduction velocity was significantly reduced (Fig. 3A) and ventricular refractory period was significantly increased (Fig. 3C) following TAC treatment in Ampk $\alpha 1^{+/+}$hearts, but not in Ampk $\alpha 1^{-/}$hearts. The probability to induce ventricular tachycardias following TAC treatment was low irrespective of the genotype (Fig. 3D). Taken together, Ampko1 is involved in cardiac electrical remodeling following pressure overload. 


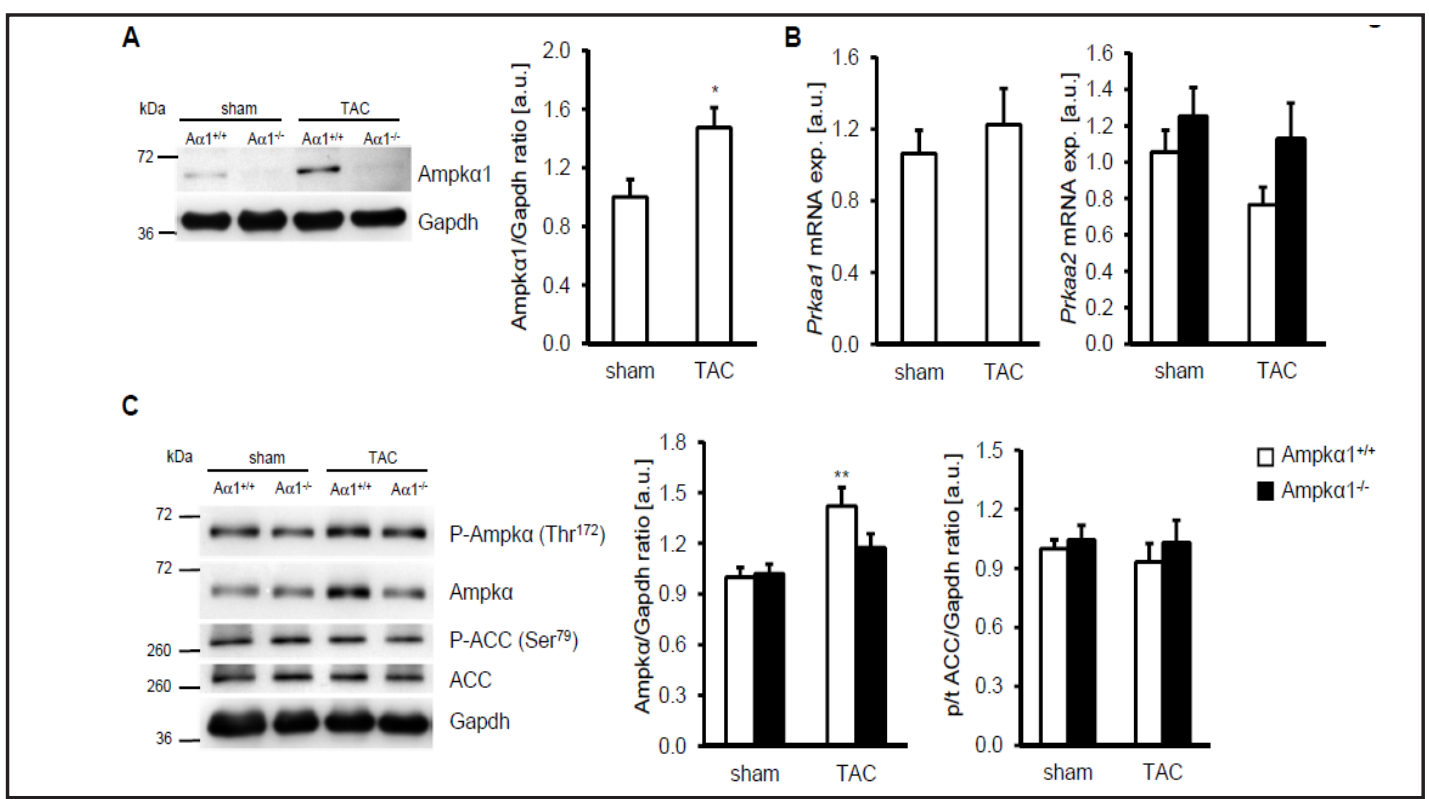

Fig. 1. Ampk $\alpha$ isoform expression in cardiac tissue from Ampko1-deficient mice following TAC. A. Representative original Western blots showing Ampk $\alpha 1$ and Gapdh protein expression in cardiac tissue from Ampk $\alpha 1$ knockout mice $\left(A \alpha 1^{-/}\right)$and respective wild-type mice $\left(A \alpha 1^{+/+}\right)$following sham procedure (sham) or transverse aortic constriction (TAC). Arithmetic means \pm SEM ( $n=10$ mice/group; arbitrary units, a.u.) of normalized Ampka1/Gapdh protein ratio in cardiac tissue from wild-type mice following sham procedure or TAC. B. Arithmetic means \pm SEM of Prkaa1 and Prkaa2 relative mRNA expression ( $\mathrm{n}=10$ mice/group; a.u.) in cardiac tissue from Ampk $\alpha 1$ knockout mice (Ampk $\alpha 1^{-/}$) and respective wild-type mice $\left(\right.$ Ampk $\left.\alpha 1^{+/+}\right)$following sham procedure or TAC. C. Representative original Western blots showing phosphoAmpk $\alpha\left(\mathrm{Thr}^{172}\right)$, Ampk $\alpha$, phospho-ACC $\left(\mathrm{Ser}^{79}\right)$, ACC and Gapdh protein expression in cardiac tissue from Ampk $\alpha 1^{\%}$ mice $\left(\mathrm{A} \alpha 1^{-/}\right)$and Ampk $\alpha 1^{+/+}$mice $\left(\mathrm{A} \alpha 1^{+/+}\right)$following sham procedure or TAC. Arithmetic means \pm SEM of normalized Ampk $\alpha /$ Gapdh protein ratio and normalized phospho-ACC/ACC/Gapdh protein ratio ( $n=12$ mice/group, a.u.) in cardiac tissue from Ampk $\alpha 1^{\%}$ mice and Ampk $\alpha 1^{+/+}$mice following sham procedure or TAC. ${ }^{*}(\mathrm{p}<0.05),{ }^{* *}(\mathrm{p}<0.01)$ statistically significant vs. respective sham mice.

In search for a structural substrate accounting for the increased conduction inhomogeneity in TAC treated Ampk $\alpha 1^{+/+}$mice, protein abundance and localization of the gap junction protein connexin 43 (Cx43) were investigated. As shown by confocal imaging and Western blotting, TAC treatment decreased the expression and deranged the organization of $\mathrm{Cx} 43$ protein in cardiac tissue from Ampk $\alpha 1^{+/+}$mice, effects mitigated in the Ampk $\alpha 1 \%$ mice (Fig. 4A,B). Furthermore, TAC treatment increased ubiquitination of $\mathrm{Cx} 43$ protein in Ampk $\alpha 1^{+/+}$mice, an effect again significantly blunted in Ampk $\alpha 1^{-/}$mice (Fig. 4C). Cx43 mRNA levels were not significantly modified by TAC treatment and were not different between Ampk $\alpha 1^{\%}$ and Ampk $\alpha 1^{+/+}$mice (Fig.4D). Thus, Ampk $\alpha 1$ down-regulates Cx43 protein abundance in cardiac tissue by increasing the ubiquitination-mediated degradation.

To further elucidate the Ampko1-sensitive regulation of the gap junction protein Cx43, Xenopus oocytes were injected with cRNA encoding Cx43-eGFP alone or together with wild-type AMPK ${ }^{\mathrm{WT}}$ (AMPK $\left.\alpha 1+\mathrm{AMPK} \beta 1+\mathrm{AMPK} \gamma 1\right)$, with catalytically inactive mutant $\mathrm{AMPK}^{\alpha \mathrm{K} 45 \mathrm{R}}\left({ }^{\mathrm{K} 45 \mathrm{R}} \mathrm{AMPK} \alpha 1+\mathrm{AMPK} \beta 1+\mathrm{AMPK} \gamma 1\right)$ or with constitutively active mutant $\mathrm{AMPK}{ }^{\gamma \mathrm{R} 70 \mathrm{Q}}$ (AMPK $\left.\alpha 1-\mathrm{HA}+\mathrm{AMPK} \beta 1+{ }^{\mathrm{R} 700} \mathrm{AMPK} \gamma 1\right)$ and $\mathrm{Cx} 43$ protein abundance in the cell membrane was determined by confocal microscopy in Cx43-eGFP-expressing Xenopus oocytes. As shown in Fig. 5A,B, the expression of Cx43-eGFP protein in the Xenopus oocytes cell membrane was significantly decreased following coexpression of wild-type AMPK ${ }^{\mathrm{WT}}$ and of constitutively active $A M P K^{\gamma R 70 Q}$. In contrast, coexpression of the catalytically inactive $A_{M P K}{ }^{\alpha K 45 R}$ did not significantly modify $\mathrm{Cx} 43-\mathrm{eGFP}$ protein cell surface expression. Thus, kinase activity is required for the effect of AMPK on Cx43 protein cell membrane abundance. 
A

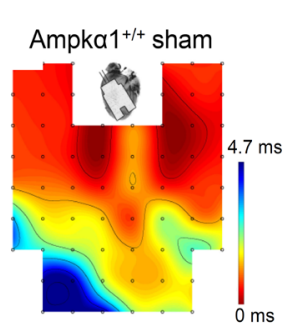

Ampka1-/- sham



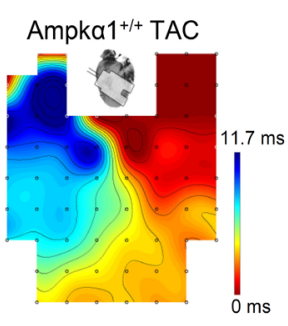

Ampka1-1- TAC

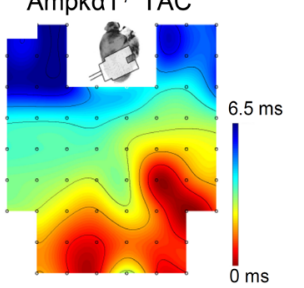

B



C

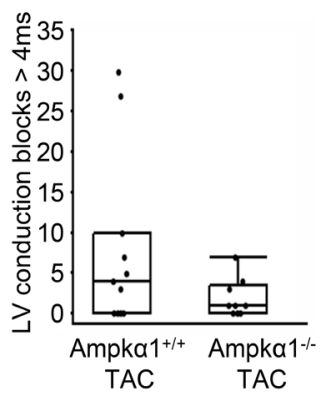

Fig. 2. Ampka1 deficiency ameliorates left ventricular conduction inhomogeneity following TAC. A. Representative left ventricular epicardial activation maps of Ampk $\alpha 1$ knockout mice (Ampko1\%) and respective wild-type mice $\left(A m p k \alpha 1^{+/+}\right)$following sham procedure (sham) or transverse aortic constriction (TAC). Activation starts with red color and propagates towards blue. Black lines represent isochrones; each $1 \mathrm{~ms}$ apart. Inlets demonstrate electrode orientation in relationship to the heart. B. Arithmetic means \pm SEM of LV inhomogeneity index ( $\mathrm{n}=6-11$ mice/group; (P5-P95)/P50) measured in Langendorff heart preparations from Ampk $\alpha 1^{-}$mice and Ampk $\alpha 1^{1 /+}$ mice following sham procedure or TAC. ${ }^{* *}(\mathrm{p}<0.01)$ statistically significant vs. respective sham mice; $\dagger(\mathrm{p}<0.05)$ statistically significant vs. respective Ampk $\alpha 1^{+/+}$ mice. C. Individual measurements and box-plots of $\mathrm{LV}$ conduction blocks $>4 \mathrm{~ms}$ (points represent individual mice) in hearts from TAC treated Ampk $\alpha 1^{\%}$ mice and Ampk $\alpha 1^{+/+}$mice $(\mathrm{p}<0.01$ generalized linear model, exponential distribution).

Fig. 3. Cardiac conduction velocity and arrhythmia induction in Ampk $\alpha 1$ deficient mice following TAC. Arithmetic means \pm SEM of longitudinal (A) and transversal (B) LV conduction velocity $(\mathrm{n}=8-12$ mice/group; $\mathrm{cm} / \mathrm{s}$ ) and of ventricular refractory period (C, $\mathrm{n}=8$-12 mice/group; $\mathrm{ms}$ ) measured in hearts from Ampko $1 \%$ mice and Ampko1 $1^{+/+}$mice following sham procedure or TAC. $*(\mathrm{p}<0.05)$ statistically significant vs. respective sham mice. D. Probability of induction of ventricular tachycardias ( $n=8-12$ mice/group; \%) in hearts from Ampk $\alpha 1^{-/}$mice and Ampk $\alpha 1^{+/+}$ mice following sham procedure or TAC.

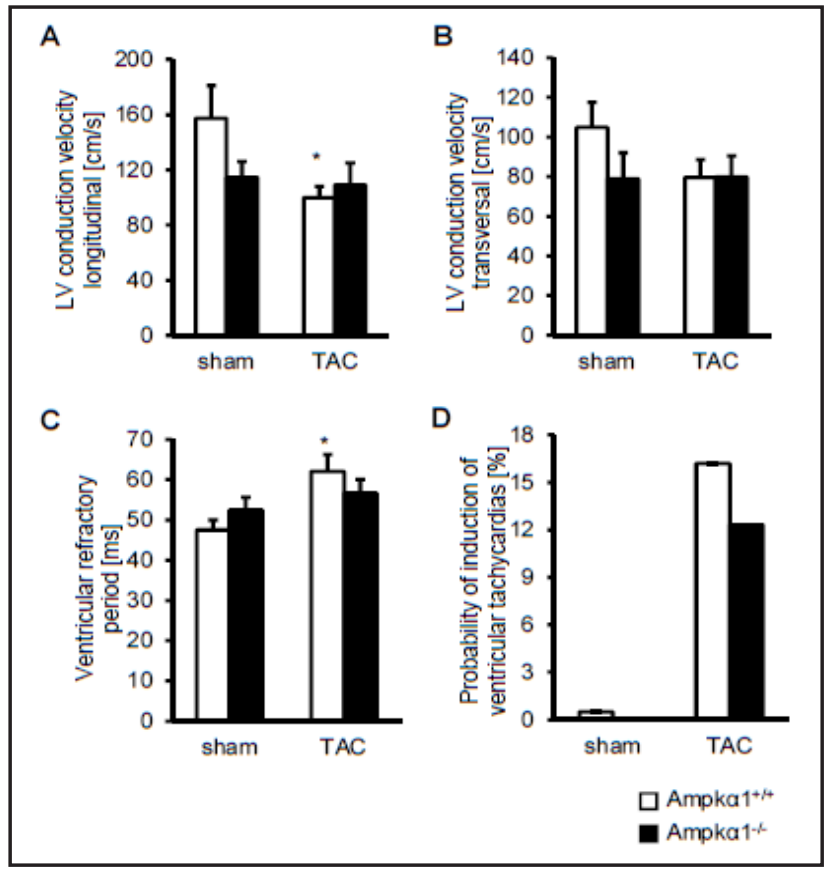






Fig. 4. Connexin 43 remodeling following TAC is mitigated by Ampk 1 deficiency. A. Confocal microscopy images showing connexin $43(\mathrm{Cx} 43)$ protein expression in cardiac tissue from Ampka1 knockout mice $\left(\right.$ Ampk $\left.\alpha 1^{\%}\right)$ and respective wild-type mice (Ampk $\alpha 1^{+/+}$) following sham procedure (sham) or transverse aortic constriction (TAC). Cx43 expression is represented by green labeling, in merged images nuclei are labeled in blue, actin staining is labeled in red. Images are representative for four mice/ group. Scale bar indicates $20 \mu \mathrm{m}$. B. Representative original Western blots and arithmetic means \pm SEM of normalized Cx43/ Gapdh protein ratio ( $\mathrm{n}=10$ mice/group; arbitrary units, a.u.) in cardiac tissue from Ampk $\alpha 1^{-\%}$ mice $\left(A \alpha 1^{-/}\right)$ and Ampk $\alpha 1^{+/+}$mice $\left(A \alpha 1^{+/+}\right)$following sham procedure or TAC. C. Representative original Western blots and arithmetic means \pm SEM of normalized $\mathrm{Cx} 43$ ubiquitination ( $\mathrm{n}=7$ mice/group; a.u) measured by ubiquitin/ $\mathrm{Cx} 43$ protein ratio in $\mathrm{Cx} 43$-immunoprecipitated cardiac samples from Ampk $\alpha 1^{-/-}$mice and Ampk $\alpha 1^{+/+}$mice following sham procedure or TAC. D. Arithmetic means \pm SEM of $C x 43$ relative mRNA expression ( $\mathrm{n}=8$ mice/ group; a.u.) in cardiac tissue from Ampk $\alpha 1^{\%}$ mice and Ampk $\alpha 1^{+/+}$mice following sham procedure or TAC. ${ }^{*}(\mathrm{p}<0.05),{ }^{* *}(\mathrm{p}<0.01),{ }^{* * *}(\mathrm{p}<0.001)$ statistically significant vs. respective sham mice; $\uparrow(\mathrm{p}<0.05)$ statistically significant vs. respective Ampk $\alpha 1^{+/+}$mice.

\section{Discussion}

The present study reveals a novel function of the AMP-activated protein kinase $\alpha 1$ (Ampko1). The kinase regulates the protein abundance of cardiac gap junction protein connexin $43(\mathrm{Cx} 43)$ and affects electrical remodeling of the heart. Cx43 dysregulation is pivotal for the electrical cardiac remodeling and may underlie enhanced susceptibility to arrhythmia in the failing heart [40]. Downregulation of Ampk $\alpha 2$ and upregulation of Ampk $\alpha 1$ pointing to an isoform shift is observed in the failing human heart [9]. Accordingly, Ampk $\alpha 1$ protein abundance was increased in cardiac tissue from wild-type mice following pressure overload induced by transverse aortic constriction (TAC).

According to the present observations, Ampk $\alpha 1$ regulates ubiquitination of the gap junction protein $\mathrm{Cx} 43$ in cardiac tissue. In contrast, Ampka1 does not appreciably alter Cx43 


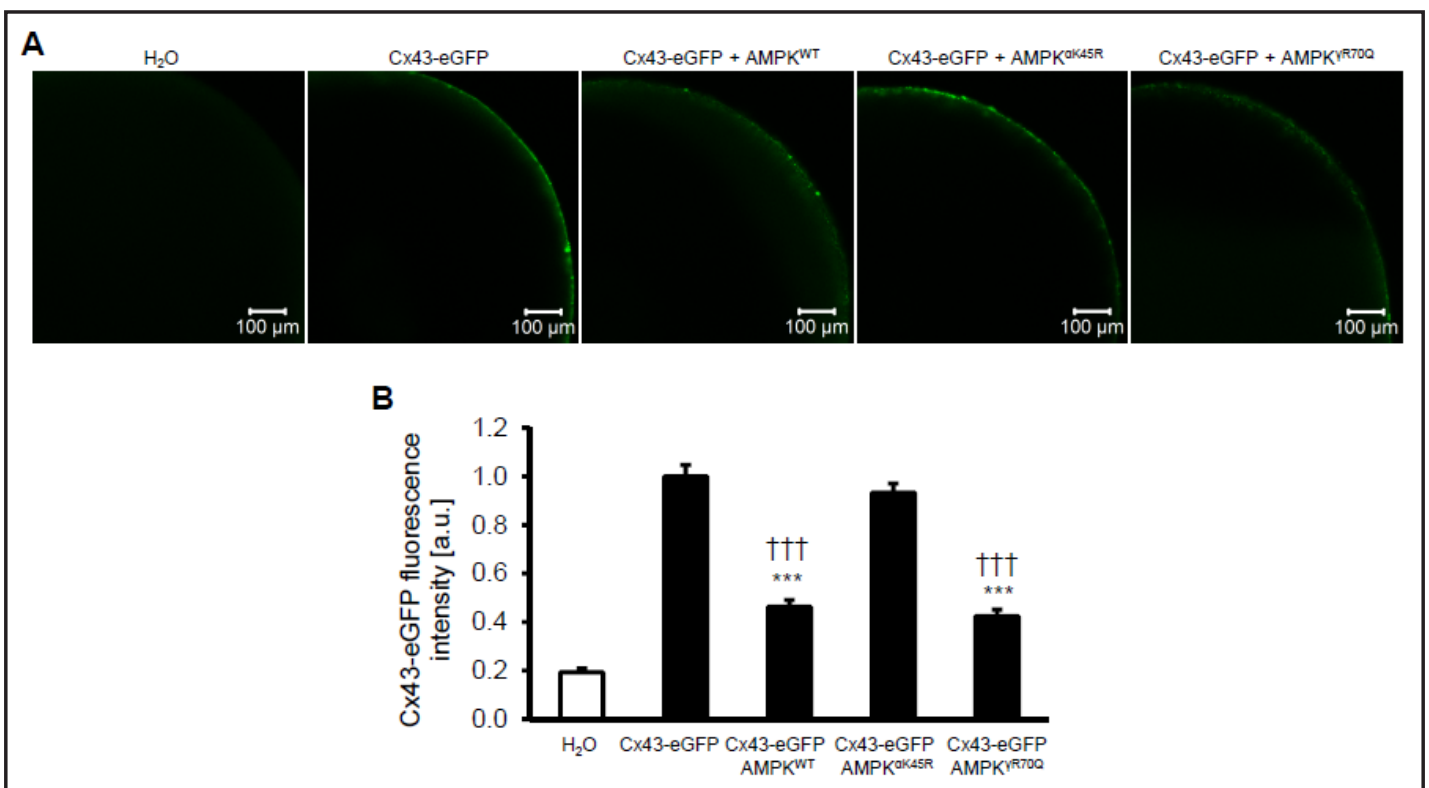

Fig. 5. Coexpression of AMPK down-regulates $\mathrm{Cx} 43$ cell membrane protein abundance in Xenopus oocytes. Representative confocal microscopy images showing Cx43-eGFP cell surface expression (A) and arithmetic means \pm SEM of normalized Cx43-eGFP fluorescence intensity (B, $n=14-17$ oocytes/group from three independent experiments; a.u.) in Xenopus oocytes injected with water $\left(\mathrm{H}_{2} \mathrm{O}\right)$, expressing $\mathrm{Cx} 43$-eGFP alone (Cx43-eGFP) or together with wild-type $\mathrm{AMPK}^{\mathrm{WT}}\left(\mathrm{Cx} 43-\mathrm{eGFP}+\mathrm{AMPK}^{\mathrm{WT}}\right)$, with catalytically inactive mutant $\mathrm{AMPK}^{\alpha \mathrm{K} 45 \mathrm{R}}\left(\mathrm{Cx} 43-\mathrm{eGFP}+\mathrm{AMPK}^{\alpha \mathrm{K} 45 \mathrm{R}}\right)$ or with constitutively active mutant $\mathrm{AMPK}^{\gamma \mathrm{R} 70 \mathrm{Q}}\left(\mathrm{Cx} 43-\mathrm{eGFP}+\mathrm{AMPK}^{\gamma \mathrm{R} 700}\right)$. Cx43-eGFP expression is represented by green fluorescence. Images are representative for 3 independent experiments. Scale bar indicates $100 \mu \mathrm{m} .{ }^{* * *}(\mathrm{p}<0.001)$ statistically significant vs. Xenopus oocytes expressing Cx43 alone. $+\dagger \dagger(\mathrm{p}<0.001)$ statistically significant vs. Xenopus oocytes coexpressing Cx43 and $\mathrm{AMPK}^{\alpha \mathrm{K} 45 \mathrm{R}}$.

transcript levels. Thus, Ampk $\alpha 1$ downregulates $\mathrm{Cx} 43$ protein abundance in cardiac tissue presumably by accelerating $\mathrm{Cx} 43$ protein degradation. The $\mathrm{Cx} 43$ protein is regulated by ubiquitination [41-43]. Ampk has previously been shown to regulate ubiquitin ligases, and thus protein degradation through the "ubiquitin proteasome system" [44-47]. Our findings suggest that Ampk $\alpha 1$ regulates the ubiquitination with subsequent internalization and degradation of the $\mathrm{Cx} 43$ protein. Along those lines the decline of $\mathrm{Cx} 43$ abundance in cardiac hypertrophy involves posttranscriptional mechanisms [48].

The reduction of $\mathrm{Cx} 43$ protein in the cell membrane presumably contributes to the observed increased LV inhomogeneity index in wild-type mice following TAC treatment. Despite the changes in the LV inhomogeneity index and $\mathrm{Cx} 43$ protein, the probability to induce ventricular tachyarrythmias was low in both genotypes following TAC procedure. Any differences in tachyarrythmia induction between the genotypes might be masked by the low susceptibility to tachyarrythmia induction in this model. The conduction velocity tended to be lower in Ampk $\alpha 1^{\%}$ mice than in Ampk $\alpha 1^{+/+}$mice, but decreased significantly following TAC treatment only in Ampk $\alpha 1^{+/+}$mice. The scatter of the data precludes safe conclusions but other mechanisms than Ampka1-sensitive Cx43 regulation may contribute to modifications of conduction velocity. Ampk sensitivity of cardiac conduction velocity may be influenced by regulation of further ion channels, such as the voltage-gated $\mathrm{Na}^{+}$channels, which are activated by Ampk [11]. Furthermore, $\mathrm{Cx} 43$ may not be the major determinant of cardiac conduction velocity $[49,50]$. Cx43 also exerts effects independent of gap junction function [51]. Nonetheless, reduction and lateralization of $\mathrm{Cx} 43$ protein causes conduction defects in the failing heart $[52,53]$. Cx43 is reduced following pressure overload induced by TAC and congestive heart failure, but $\mathrm{Cx} 43$ is not decisive for cardiac contractile function [54-56]. 
The downregulation of connexins by Ampk presumably serves to protect neighbours of energy depleted cells from $\mathrm{Na}^{+}$and $\mathrm{K}^{+}$fluxes through gap junctions due to impaired $\mathrm{Na}^{+} / \mathrm{K}^{+}$ATPase activity in energy depleted cells [57]. Cx43 internalization is an important mechanism during cardiac ischemia [58]. Cardiac ischemia activates Ampk $\alpha 1$ [59], which exerts protective effects in the ischemic heart $[60,61]$. Similarly, inhibition of $\mathrm{Cx} 43$ mitigates cardiac ischemia reperfusion injury [62]. Inhibition of $\mathrm{Cx} 43$ by Ampk could serve to protect the heart from ischemic episodes. Chronic pressure overload causes activation and increased activity of Ampk [8]. During chronic activation, such as in heart failure, the inhibitory actions of Ampk on Cx43 might lead to detrimental loss of gap junctions and impaired cardiac conductance.

Mutations in the gamma subunit of Ampk are associated with increased Ampk activity, ventricular preexcitation and conduction defects $[63,64]$. The effects of the mutated Ampk are not solely due to increased glycogen storage [36]. Ampk activity is increased following pressure overload, increasing the expression of the Ampk $\alpha 1$ isoform, but rather reducing the Ampk $\alpha 2$ isoform [8]. Ampk $\alpha 2$ activation is protective in the failing heart [5]. Ampk $\alpha 2$ deficient mice, but not Ampka1-deficient mice show dysfunctional expression of energy metabolism-related genes and exacerbated remodeling following TAC $[65,66]$. Therefore, the effects of Ampk $\alpha 1$ could be of significant importance especially in the failing heart.

In conclusion, Ampk $\alpha 1$ negatively regulates $\mathrm{Cx} 43$ protein expression by increasing the ubiquitination-mediated degradation and thus impacts on gap junction coupling. These observations suggest that the previously observed isoform shift towards Ampk $\alpha 1$ in human heart failure and an increased Ampko1 activity [9] may cause detrimental effects on gap junction remodeling.

\section{Acknowledgements}

The authors gratefully acknowledge Dr. Benoit Viollet for providing the Ampk $\alpha 1^{\%}$ mouse and Dr. Klaus Willecke for providing the Cx43 construct. The authors are grateful for the outstanding technical assistance of Elfriede Faber, for support by Miribane DërmakuSopjani and the meticulous preparation of the manuscript by Lejla Subasic and Tanja Loch.

This work was supported by grants from the Deutsche Forschungsgemeinschaft (La315/4-5, SFB-Transregio 19, BO 3786/1-1), Open Access Publishing Fund of Tuebingen University, the German Cardiac Society (DGK Stipendium 2012) and the European Union Seventh Framework Programme (FP7/2007-2013) under grant agreement: 603288.

\section{Disclosures Statement}

None.

\section{References}

1 Fontes MS, van Veen TA, de Bakker JM, van Rijen HV: Functional consequences of abnormal Cx43 expression in the heart. Biochim Biophys Acta 2012;1818:2020-2029.

- Hesketh GG, Van Eyk JE, Tomaselli GF: Mechanisms of gap junction traffic in health and disease. J Cardiovasc Pharmacol 2009;54:263-272.

-3 Cutler MJ, Jeyaraj D, Rosenbaum DS: Cardiac electrical remodeling in health and disease. Trends Pharmacol Sci 2011;32:174-180.

-4 Ghali JK, Kadakia S, Cooper RS, Liao YL: Impact of left ventricular hypertrophy on ventricular arrhythmias in the absence of coronary artery disease. J Am Coll Cardiol 1991;17:1277-1282.

-5 Zaha VG, Young LH: AMP-activated protein kinase regulation and biological actions in the heart. Circ Res 2012;111:800-814.

-6 Towler MC, Hardie DG: AMP-activated protein kinase in metabolic control and insulin signaling. Circ Res 2007;100:328-341.

7 Viollet B, Horman S, Leclerc J, Lantier L, Foretz M, Billaud M, Giri S, Andreelli F: AMPK inhibition in health and disease. Crit Rev Biochem Mol Biol 2010;45:276-295. 
8 Tian R, Musi N, D'Agostino J, Hirshman MF, Goodyear LJ: Increased adenosine monophosphate-activated protein kinase activity in rat hearts with pressure-overload hypertrophy. Circulation 2001;104:1664-1669.

-9 Kim M, Shen M, Ngoy S, Karamanlidis G, Liao R, Tian R: AMPK isoform expression in the normal and failing hearts. J Mol Cell Cardiol 2012;52:1066-1073.

10 Alesutan I, Munoz C, Sopjani M, Dermaku-Sopjani M, Michael D, Fraser S, Kemp BE, Seebohm G, Foller M, Lang F: Inhibition of Kir2.1 (KCNJ2) by the AMP-activated protein kinase. Biochem Biophys Res Commun 2011;408:505-510.

11 Light PE, Wallace CH, Dyck JR: Constitutively active adenosine monophosphate-activated protein kinase regulates voltage-gated sodium channels in ventricular myocytes. Circulation 2003;107:1962-1965.

12 Alesutan I, Sopjani M, Munoz C, Fraser S, Kemp BE, Foller M, Lang F: Inhibition of connexin 26 by the AMPactivated protein kinase. J Membr Biol 2011;240:151-158.

13 Gusarova GA, Dada LA, Kelly AM, Brodie C, Witters LA, Chandel NS, Sznajder JI: Alpha1-AMP-activated protein kinase regulates hypoxia-induced $\mathrm{Na}, \mathrm{K}-\mathrm{ATP}$ ase endocytosis via direct phosphorylation of protein kinase C zeta. Mol Cell Biol 2009;29:3455-3464.

14 Vadasz I, Dada LA, Briva A, Trejo HE, Welch LC, Chen J, Toth PT, Lecuona E, Witters LA, Schumacker PT, Chandel NS, Seeger W, Sznajder JI: AMP-activated protein kinase regulates CO2-induced alveolar epithelial dysfunction in rats and human cells by promoting Na,K-ATPase endocytosis. J Clin Invest 2008;118:752762.

15 Bhavsar SK, Schmidt S, Bobbala D, Nurbaeva MK, Hosseinzadeh Z, Merches K, Fajol A, Wilmes J, Lang F: AMPKalpha1-sensitivity of Orai1 and $\mathrm{Ca}(2+)$ entry in T - lymphocytes. Cell Physiol Biochem 2013;32:687698.

16 Langelueddecke C, Jakab M, Ketterl N, Lehner L, Hufnagl C, Schmidt S, Geibel JP, Fuerst J, Ritter M: Effect of the AMP-kinase modulators AICAR, metformin and compound C on insulin secretion of INS-1E rat insulinoma cells under standard cell culture conditions. Cell Physiol Biochem 2012;29:75-86.

17 Mia S, Munoz C, Pakladok T, Siraskar G, Voelkl J, Alesutan I, Lang F: Downregulation of Kv1.5 K channels by the AMP-activated protein kinase. Cell Physiol Biochem 2012;30:1039-1050.

18 Zhu Y, Wu J, Yuan SY: MCT1 and MCT4 expression during myocardial ischemic-reperfusion injury in the isolated rat heart. Cell Physiol Biochem 2013;32:663-674.

19 Alesutan I, Foller M, Sopjani M, Dermaku-Sopjani M, Zelenak C, Frohlich H, Velic A, Fraser S, Kemp BE, Seebohm G, Volkl H, Lang F: Inhibition of the heterotetrameric K+ channel KCNQ1/KCNE1 by the AMPactivated protein kinase. Mol Membr Biol 2011;28:79-89.

20 Kim M, Hunter RW, Garcia-Menendez L, Gong G, Yang YY, Kolwicz SC, Jr., Xu J, Sakamoto K, Wang W, Tian R: Mutation in the gamma2-subunit of AMP-activated protein kinase stimulates cardiomyocyte proliferation and hypertrophy independent of glycogen storage. Circ Res 2014;114:966-975.

-21 Jorgensen SB, Viollet B, Andreelli F, Frosig C, Birk JB, Schjerling P, Vaulont S, Richter EA, Wojtaszewski JF: Knockout of the alpha2 but not alpha1 5'-AMP-activated protein kinase isoform abolishes 5-aminoimidazole-4-carboxamide-1-beta-4-ribofuranosidebut not contraction-induced glucose uptake in skeletal muscle. J Biol Chem 2004;279:1070-1079.

22 Schuhmacher S, Foretz M, Knorr M, Jansen T, Hortmann M, Wenzel P, Oelze M, Kleschyov AL, Daiber A, Keaney JF, Jr., Wegener G, Lackner K, Munzel T, Viollet B, Schulz E: alpha1AMP-activated protein kinase preserves endothelial function during chronic angiotensin II treatment by limiting Nox2 upregulation. Arterioscler Thromb Vasc Biol 2011;31:560-566.

23 Voelkl J, Lin Y, Alesutan I, Ahmed MS, Pasham V, Mia S, Gu S, Feger M, Saxena A, Metzler B, Kuhl D, Pichler BJ, Lang F: Sgk1 sensitivity of $\mathrm{Na}(+) / \mathrm{H}(+)$ exchanger activity and cardiac remodeling following pressure overload. Basic Res Cardiol 2012;107:236.

24 Kreuzberg MM, Schrickel JW, Ghanem A, Kim JS, Degen J, Janssen-Bienhold U, Lewalter T, Tiemann K, Willecke K: Connexin30.2 containing gap junction channels decelerate impulse propagation through the atrioventricular node. Proc Natl Acad Sci U S A 2006;103:5959-5964.

-25 Schrickel JW, Brixius K, Herr C, Clemen CS, Sasse P, Reetz K, Grohe C, Meyer R, Tiemann K, Schroder R, Bloch W, Nickenig G, Fleischmann BK, Noegel AA, Schwinger RH, Lewalter T: Enhanced heterogeneity of myocardial conduction and severe cardiac electrical instability in annexin A7-deficient mice. Cardiovasc Res 2007;76:257-268.

26 Schrickel JW, Stockigt F, Krzyzak W, Paulin D, Li Z, Lubkemeier I, Fleischmann B, Sasse P, Linhart M, Lewalter T, Nickenig G, Lickfett L, Schroder R, Clemen CS: Cardiac conduction disturbances and differential effects on atrial and ventricular electrophysiological properties in desmin deficient mice. J Interv Card 
Electrophysiol 2010;28:71-80.

27 Lammers WJ, Schalij MJ, Kirchhof CJ, Allessie MA: Quantification of spatial inhomogeneity in conduction and initiation of reentrant atrial arrhythmias. Am J Physiol 1990;259:H1254-1263.

-28 Voelkl J, Alesutan I, Leibrock CB, Quintanilla-Martinez L, Kuhn V, Feger M, Mia S, Ahmed MS, Rosenblatt KP, Kuro OM, Lang F: Spironolactone ameliorates PIT1-dependent vascular osteoinduction in klothohypomorphic mice. J Clin Invest 2013;123:812-822.

-29 Fraser SA, Gimenez I, Cook N, Jennings I, Katerelos M, Katsis F, Levidiotis V, Kemp BE, Power DA: Regulation of the renal-specific Na+-K+-2Cl- co-transporter NKCC2 by AMP-activated protein kinase (AMPK). Biochem J 2007;405:85-93.

30 Hamilton SR, Stapleton D, O'Donnell JB, Jr., Kung JT, Dalal SR, Kemp BE, Witters LA: An activating mutation in the gamma1 subunit of the AMP-activated protein kinase. FEBS Lett 2001;500:163-168.

-31 Hallows KR, Kobinger GP, Wilson JM, Witters LA, Foskett JK: Physiological modulation of CFTR activity by AMP-activated protein kinase in polarized T84 cells. Am J Physiol Cell Physiol 2003;284:C1297-C1308.

-32 Warsi J, Dong L, Elvira B, Salker MS, Shumilina E, Hosseinzadeh Z, Lang F: SPAK Dependent Regulation of Peptide Transporters PEPT1 and PEPT2. Kidney Blood Press Res 2014;39:388-398.

33 Elvira B, Munoz C, Borras J, Chen H, Warsi J, Ajay SS, Shumilina E, Lang F: SPAK and OSR1 Dependent Down-Regulation of Murine Renal Outer Medullary K Channel ROMK1. Kidney Blood Press Res 2014;39:353-360.

-34 Munoz C, Pakladok T, Almilaji A, Elvira B, Decher N, Shumilina E, Lang F: Up-regulation of Kir2.1 (KCNJ2) by the serum \& glucocorticoid inducible SGK3. Cell Physiol Biochem 2014;33:491-500.

35 Dërmaku-Sopjani M, Almilaji A, Pakladok T, Munoz C, Hosseinzadeh Z, Blecua M, Sopjani M, Lang F: Downregulation of the Na+-coupled phosphate transporter NaPi-IIa by AMP-activated protein kinase. Kidney Blood Press Res 2013;37:547-556.

-36 Bukauskas FF, Kreuzberg MM, Rackauskas M, Bukauskiene A, Bennett MV, Verselis VK, Willecke K: Properties of mouse connexin 30.2 and human connexin 31.9 hemichannels: implications for atrioventricular conduction in the heart. Proc Natl Acad Sci U S A 2006;103:9726-9731.

37 O'Connor CM, Smith LD: Inhibition of oocyte maturation by theophylline: possible mechanism of action. Dev Biol 1976;52:318-322.

-38 Pakladok T, Almilaji A, Munoz C, Alesutan I, Lang F: PIKfyve sensitivity of hERG channels. Cell Physiol Biochem 2013;31:785-794.

-39 Ussher JR, Lopaschuk GD: Targeting malonyl CoA inhibition of mitochondrial fatty acid uptake as an approach to treat cardiac ischemia/reperfusion. Basic Res Cardiol 2009;104:203-210.

40 Boulaksil M, Winckels SK, Engelen MA, Stein M, van Veen TA, Jansen JA, Linnenbank AC, Bierhuizen MF, Groenewegen WA, van Oosterhout MF, Kirkels JH, de Jonge N, Varro A, Vos MA, de Bakker JM, van Rijen $\mathrm{HV}$ : Heterogeneous Connexin43 distribution in heart failure is associated with dispersed conduction and enhanced susceptibility to ventricular arrhythmias. Eur J Heart Fail 2010;12:913-921.

41 Laing JG, Beyer EC: The gap junction protein connexin43 is degraded via the ubiquitin proteasome pathway. J Biol Chem 1995;270:26399-26403.

42 Leithe E, Rivedal E: Ubiquitination of gap junction proteins. J Membr Biol 2007;217:43-51.

43 Leithe E, Rivedal E: Ubiquitination and down-regulation of gap junction protein connexin-43 in response to 12-O-tetradecanoylphorbol 13-acetate treatment. J Biol Chem 2004;279:50089-50096.

44 Bhalla V, Oyster NM, Fitch AC, Wijngaarden MA, Neumann D, Schlattner U, Pearce D, Hallows KR: AMPactivated kinase inhibits the epithelial $\mathrm{Na}+$ channel through functional regulation of the ubiquitin ligase Nedd4-2. J Biol Chem 2006;281:26159-26169.

\$4 Alzamora R, Gong F, Rondanino C, Lee JK, Smolak C, Pastor-Soler NM, Hallows KR: AMP-activated protein kinase inhibits KCNQ1 channels through regulation of the ubiquitin ligase Nedd4-2 in renal epithelial cells. Am J Physiol Renal Physiol 2010;299:F1308-1319.

-46 Baskin KK, Taegtmeyer H: AMP-activated protein kinase regulates E3 ligases in rodent heart. Circ Res 2011;109:1153-1161.

47 Tong JF, Yan X, Zhu MJ, Du M: AMP-activated protein kinase enhances the expression of muscle-specific ubiquitin ligases despite its activation of IGF-1/Akt signaling in C2C12 myotubes. J Cell Biochem 2009;108:458-468.

48 Bierhuizen MF, Boulaksil M, van Stuijvenberg L, van der Nagel R, Jansen AT, Mutsaers NA, Yildirim C, van Veen TA, de Windt LJ, Vos MA, van Rijen HV: In calcineurin-induced cardiac hypertrophy expression of Nav1.5, Cx40 and Cx43 is reduced by different mechanisms. J Mol Cell Cardiol 2008;45:373-384. 
49 Morley GE, Vaidya D, Samie FH, Lo C, Delmar M, Jalife J: Characterization of conduction in the ventricles of normal and heterozygous Cx43 knockout mice using optical mapping. J Cardiovasc Electrophysiol 1999;10:1361-1375.

-50 van Rijen HV, Eckardt D, Degen J, Theis M, Ott T, Willecke K, Jongsma HJ, Opthof T, de Bakker JM: Slow conduction and enhanced anisotropy increase the propensity for ventricular tachyarrhythmias in adult mice with induced deletion of connexin43. Circulation 2004;109:1048-1055.

51 Lubkemeier I, Requardt RP, Lin X, Sasse P, Andrie R, Schrickel JW, Chkourko H, Bukauskas FF, Kim JS, Frank M, Malan D, Zhang J, Wirth A, Dobrowolski R, Mohler PJ, Offermanns S, Fleischmann BK, Delmar M, Willecke K: Deletion of the last five C-terminal amino acid residues of connexin43 leads to lethal ventricular arrhythmias in mice without affecting coupling via gap junction channels. Basic Res Cardiol 2013;108:348.

52 Schrickel JW, Lickfett L, Lewalter T, Tiemann K, Nickenig G, Baba H, Heusch G, Schulz R, Levkau B: Cardiomyocyte-specific deletion of survivin causes global cardiac conduction defects. Basic Res Cardiol 2012;107:299.

53 Chkourko HS, Guerrero-Serna G, Lin X, Darwish N, Pohlmann JR, Cook KE, Martens JR, Rothenberg E, Musa $\mathrm{H}$, Delmar M: Remodeling of mechanical junctions and of microtubule-associated proteins accompany cardiac connexin43 lateralization. Heart Rhythm 2012;9:1133-1140 e1136.

54 Bruce AF, Rothery S, Dupont E, Severs NJ: Gap junction remodelling in human heart failure is associated with increased interaction of connexin43 with ZO-1. Cardiovasc Res 2008;77:757-765.

-55 Teunissen BE, Jongsma HJ, Bierhuizen MF: Regulation of myocardial connexins during hypertrophic remodelling. Eur Heart J 2004;25:1979-1989.

56 Betsuyaku T, Kovacs A, Saffitz JE, Yamada KA: Cardiac structure and function in young and senescent mice heterozygous for a connexin43 null mutation. J Mol Cell Cardiol 2002;34:175-184.

57 Lang F, Busch GL, Ritter M, Volkl H, Waldegger S, Gulbins E, Haussinger D: Functional significance of cell volume regulatory mechanisms. Physiol Rev. 1998;78:247-306.

-58 Smyth JW, Zhang SS, Sanchez JM, Lamouille S, Vogan JM, Hesketh GG, Hong T, Tomaselli GF, Shaw RM: A 14-3-3 mode-1 binding motif initiates gap junction internalization during acute cardiac ischemia. Traffic 2014;15:684-699.

-59 Li J, Coven DL, Miller EJ, Hu X, Young ME, Carling D, Sinusas AJ, Young LH: Activation of AMPK alphaand gamma-isoform complexes in the intact ischemic rat heart. Am J Physiol Heart Circ Physiol 2006;291:H1927-1934.

60 Pei H, Qu Y, Lu X, Yu Q Lian K, Liu P, Yan W, Liu J, Ma Y, Liu Y, Li C, Li W, Lau WB, Zhang H, Tao L: Cardiacderived adiponectin induced by long-term insulin treatment ameliorates myocardial ischemia/reperfusion injury in type 1 diabetic mice via AMPK signaling. Basic Res Cardiol 2013;108:322.

61 Russell RR, 3rd, Li J, Coven DL, Pypaert M, Zechner C, Palmeri M, Giordano FJ, Mu J, Birnbaum MJ, Young LH: AMP-activated protein kinase mediates ischemic glucose uptake and prevents postischemic cardiac dysfunction, apoptosis, and injury. J Clin Invest 2004;114:495-503.

62 Wang N, De Vuyst E, Ponsaerts R, Boengler K, Palacios-Prado N, Wauman J, Lai CP, De Bock M, Decrock E, Bol M, Vinken M, Rogiers V, Tavernier J, Evans WH, Naus CC, Bukauskas FF, Sipido KR, Heusch G, Schulz R, Bultynck G, Leybaert L: Selective inhibition of Cx43 hemichannels by Gap19 and its impact on myocardial ischemia/reperfusion injury. Basic Res Cardiol 2013;108:309.

63 Arad M, Benson DW, Perez-Atayde AR, McKenna WJ, Sparks EA, Kanter RJ, McGarry K, Seidman JG, Seidman CE: Constitutively active AMP kinase mutations cause glycogen storage disease mimicking hypertrophic cardiomyopathy. J Clin Invest 2002;109:357-362.

64 Luptak I, Shen M, He H, Hirshman MF, Musi N, Goodyear LJ, Yan J, Wakimoto H, Morita H, Arad M, Seidman CE, Seidman JG, Ingwall JS, Balschi JA, Tian R: Aberrant activation of AMP-activated protein kinase remodels metabolic network in favor of cardiac glycogen storage. J Clin Invest 2007;117:1432-1439.

65 Zhang P, Hu X, Xu X, Fassett J, Zhu G, Viollet B, Xu W, Wiczer B, Bernlohr DA, Bache RJ, Chen Y: AMP activated protein kinase-alpha2 deficiency exacerbates pressure-overload-induced left ventricular hypertrophy and dysfunction in mice. Hypertension 2008;52:918-924.

66 Xu X, Lu Z, Fassett J, Zhang P, Hu X, Liu X, Kwak D, Li J, Zhu G, Tao Y, Hou M, Wang H, Guo H, Viollet B, McFalls EO, Bache RJ, Chen Y: Metformin Protects Against Systolic Overload-Induced Heart Failure Independent of AMP-Activated Protein Kinase alpha2. Hypertension 2014;10.1161/ HYPERTENSIONAHA.113.02619 